Instructions for authors, subscriptions and further details:

\title{
http://rise.hipatiapress.com
}

\section{Higher Education and the Challenges for Economic Growth in Mozambique: Some Evidence}

Pedro Uetela ${ }^{1}$

1) Universidade Estadual Paulista Júlio de Mesquita Filho, Brasil

Date of publication: October $25^{\text {th }}, 2015$

Edition period: October 2015-February 2016

To cite this article: uetela, P. (2015). Higher Education and the Challenges for Economic Growth in Mozambique: Some Evidence. International Journal of Sociology of Education, 4(3), 276-294. doi: 10.17583/rise.2015.1751

To link this article: http://dx.doi.org/10.17583/rise.2015.1751

PLEASE SCROLL DOWN FOR ARTICLE

The terms and conditions of use are related to the Open Journal System and to Creative Commons Attribution License (CC-BY) 


\section{Higher Education and the Challenges for Economic Growth in Mozambique: Some Evidence}

Pedro Uetela

Universidade Estadual Paulista Júlio

de Mesquita Filho

(Received: 1 October 2015; Accepted: 11 october 2015; Published: 25

October 2015)

\section{Abstract}

There has been an increasing debate on higher education (HE) transformation in developing countries over the past decades. The main assumption underlying this focus often centers on the arguments contrary to the dominant narratives, which have been skeptical that HE plays a considerable role for economic and social transformation. The rise of certain Asian economies including Taiwan and South Korea, which were at the same level in terms of GDP with African nation states such as Nigeria, Tanzania and Ghana in the 1960s, has confirmed the theory that maximization of knowledge is key to achieve development. Furthermore, the successful stories from the newly industrialized countries especially the BRICS have considerably increased the possibilities that Mozambique can learn from borrowed and contextualized policies from those states. In this article I highlight the main changes that have recently shaped HE policy and governance including today challenges it faces. In so doing, I outline recommendations for both policy makers and higher education leaders on how they can make appropriation of the experiences that have worked in the global context to ensure the creation of local workforce capable of driving both economic and social development in the country based on knowledge investment.

Keywords: higher education, Mozambique, knowledge economy, development 


\section{Educación Superior y los Retos para el Crecimiento Económico en \\ Mozambique: Algunas Evidencias}

Pedro Uetela

Universidade Estadual Paulista Júlio de Mesquita Filho

(Recibido: 1 Octubre 2015; Aceptado: 11 Octubre 2015; Publicado: 25

Octubre 2015)

\section{Resumen}

Ha habido un debate creciente sobre la educación superior (ES) de transformación en los países en desarrollo en las últimas décadas. La principal hipótesis que subyace a este enfoque se centra a menudo en los argumentos contrarios a las narrativas dominantes, que han sido escépticos de que ello juega un papel importante para la transformación económica y social. El auge de ciertas economías asiáticas como Taiwán y Corea del Sur, que estaban en el mismo nivel en términos de PIB con los estados nacionales africanos como Nigeria, Tanzania y Ghana en la década de 1960, ha confirmado la teoría de que la maximización del conocimiento es clave para lograr el desarrollo. Además, las historias de éxito de los nuevos países industrializados, especialmente los BRICS han aumentado considerablemente las posibilidades de que Mozambique se puede aprender de las políticas prestadas y contextualizadas de esos estados. En este artículo se destacan los principales cambios que han dado forma a la política de HE y a la gobernanza incluidos los desafíos que hoy enfrenta. Al hacerlo, esbozo recomendaciones tanto para los responsables políticos y líderes de educación superior sobre cómo pueden hacer que la apropiación de las experiencias que han funcionado en el contexto global para garantizar la creación de mano de obra local capaz de impulsar el desarrollo económico y social en el país con base de la inversión del conocimiento.

Palabras clave: educación superior, Mozambique, economía del conocimiento, desarrollo 


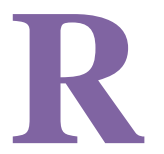

ecently, the government of Mozambique launched a strategic plan, which unveils a regulatory framework for both public and private universities. This reform appeared to be an extension of other associated policies in the country that had been initiated since the eve of independences when an increasing debate on the role of universities as key delivers and producers of knowledge required for development either in Mozambique and elsewhere in Africa were initiated. (Cloete et al, 2004; Agbo, 2003, Castells, 2001).

Furthermore, transformation in higher education governance and policy in the country have been in the last decades fostered through the establishment of ambitious strategic plans in higher education with the objective of transforming the country into a high income state firstly by 2010 and recently this target was extended to 2020 through the 2012-2020 higher education pacification. Researchers have started predicting some of the challenges the country will face in order to attain some of the aims this strategic plan has set to address, with especial focus for growth implications. Empirical evidence on higher education trajectory and current outcomes, appear to increasingly question the possibility of Mozambique achieving the targets it has set to attain within the period pre-established (2012-2020).

Whereas some countries which have been affected by similar problems that Mozambique struggles with today, have been able to emerge as new giants as is the case of (Brazil, Russia, India, China and South Africa), it appears that Mozambique has moved slow and uncertain on the link between policy and governance reforms in higher education versus economic development. The failures of the country in providing outcomes that ensure the association between reforms that have been undertaken since versus socio and economic growth, may confirm on one hand the scepticism of the international agencies that have been systematically reluctant to higher education in developing countries. Mozambique may fall under this scepticism given that, though it has undergone several reforms through the application of various strategies, those have not yet led the country to outcomes that are sufficiently relevant to ensure higher education is contributing for development. (Nyangau, 2014, p. 3).

Despite the above arguments, this paper argues instead that Mozambique can learn from successful experiences of both newly industrialized and Asian economies that grew rapidly through investment on knowledge 
generation. (ABD, 2007). The paper does so by identifying the main challenges facing Mozambique higher education and then suggest possible strategies that both policy makers and higher education control agents can apply in order to firstly attain the success other countries elsewhere have been able to achieve in linking knowledge and growth. Secondly it shows which steps Mozambique needs to consider in order to maximize the species of capitals (human, economic, symbolic, cultural and social) that are necessary to construct such knowledge economy. (Peters, 2013, p. 47).

Since borrowed and uncontextualized policies have been addressed as part of underdevelopment in Mozambique, the author is highly concerned with this. However, as Chang (2010) argues with regards to Africa tragedy to develop, rethinking growth in Mozambique, it often needs a disassociation with political, historical, geographic, economic and social landscape that characterized the nation in order to learn from other countries that have been successful. Appropriate policy borrowing has often determined the success of many states globally and hence the same might be thought of Mozambique when it shifts from policies of governance that have been dominant.

\section{Mozambique Current Strategies that Attempt to Link Higher Education Transformation and Development}

When in 2012 the Mozambican ministry of education launched a new strategic plan for higher education, which was an extension of the precedent plan propelled in 2006-2010, the underlying focus for both former and latter programs was centered on the view that higher education is most likely to foster economic growth in the country provided it responds to three (3) main challenges namely (i) demand for access, (ii) supply of sufficient higher education institutions and (iii) regulatory frameworks. (Mozambique strategic plan for higher education: 2012-2020, p. 1). The concerns on these three areas that Mozambique has determined as fundamental to address are related to the view that on one hand higher education has expanded considerably in the last three decades. As a result, statistical records point to a considerable increase from 12000 students attending higher education in 2000 to 101000 in 2010. On the other hand and despite this apparent rise, higher education in the country has not yet been able to respond neither to 
the challenges of demand for nor for the supply of institutions that are sufficient to accommodate all higher education aged students (AHEAS). In addition, regulation has been seen as another main arena that government and policy makers should concentrate efforts as if once these upheavals are overcome, then higher education will be most likely to contribute for economic development in the country. The two strategies privileged by the Mozambican government also highlight the uniqueness of higher education and the need for specific policies for the system. One of the driving forces for this uniqueness both within Mozambique and across, has increased considerably with the new trends that have been shaping higher education, including institutional internationalization, teaching and research nexus, mobility for both students and staff and life long learning. In Mozambique, all these politics appeared to be integrated under the bologna implementation attempt, a strategy that failed to materialize the objectives that higher education system had instituted to achieve. Despite unceasing efforts for Mozambique to innovate its higher education system through constant plans, as it appears to be the case since 2006-2010 and recently through the future prediction of higher education landscape till 2020, the outcomes of the association between higher education and economic growth in the country have been contrary to the objectives. Researchers have been concerned with the link between the Mozambique maximization of these efforts to associate higher education and growth on one hand and the outcomes it has been able to offer on the other. The gap between the two seems to be wider and conflicting.

There are various challenges being addressed in line with the strategies adopted including (i) quality of both expansion and access in higher education, (ii) contextualization of policy and governance weaknesses and (iii) lack of emphasis on knowledge especially in a period where the newly industrialized economies have increasingly based their transformation efforts on grounds of knowledge.

\section{Quality, Expansion and Access of Higher Education in Mozambique}

The complexity of defining quality in higher education has been debatable by various scholars. In Africa, Nyangau (2014) has considered recent developments on the complexity of quality discussion in higher education as 
follow:

Quality is a difficult concept to define, at least in higher education, because the term means different things to different stakeholders including students, taxpayers, employers, government, and quality assurance agencies. Harvey and Green (1993) identify five "discrete" yet overlapping dimensions or conceptions of quality, which I briefly revisit here. In the view of some, quality refers to the notion of a product or service being exceptional, distinctive, or special. But to define quality this way in a complex field such as education is problematic as there really are no clear criteria for conferring "special" status to a service or product. Other stakeholders view quality as a measure of perfection a state (hypothetically) achieved when a system of education produces "flawless" graduates that meet a set of predetermined specifications on a consistent basis (Harvey \& Green, 1993). But Harvey and Green (1993) point out that this approach is also insufficient as it may lead to simplistic, yet strict adherence to a set of standards, which may be narrowly defined or focused to the exclusion of other more substantive issues. Quality can also be interpreted as fitness for purpose and proponents of this stance see education's main role most often as training individuals for employment and believe that quality is achieved if an education system produces graduates that are fit for their roles as workers in the existing society. [...]. (Nyangau, 2014, p. 8).

The debate of quality in higher education in Mozambique remains novel and alien as it only emerges in the 2000s. According to Premugy (2012), the establishing of the national system for quality assurance in order to guarantee that higher education responds to the internal demands as well as to both regional and global patterns of excellence, appeared as a decree of the council of ministers in 2003. (p. 10). In line with quality assurance, was the institutionalization of the national system of evaluation and accreditation of higher education institutions. All these regulatory frameworks for both assessment and evaluation of quality were only approved by the council of ministers in 2007. (Premugy, 2012, p. 8).

One can sum up the objectives of the Mozambican institutionalization of the national system of evaluation, accreditation and quality assurance in 
higher education (SINAQES) in four main perspectives namely; (i) to ensure the aims set to measure excellence in higher education are attained and are operationalized by various stakeholders, (ii) to set norms and procedures within which higher education institutions are to operate and assess their performance through self-evaluation, (iii) to establish norms and mechanisms through which external entities can apply and be guided with in order to assess performance of higher education institutions through external evaluation and (iv) internally, how to accredit higher education institutions.

Within these conditions under which quality assessment was institutionalized in Mozambique and taking into account that one of the aims of this study is to point to some of the challenges that have shaped higher education in order to provide insights on how Mozambican policy planners and higher education leaders can combine efforts to further reform higher education so that it can creates skilled workforce that the country needs to drive its socio and economic transformation, there are various critics that can herein be pointed out.

First and foremost, is that the issue of quality in higher education in Mozambique is both novel and alien. There are various hypotheses to be formulated from this late quality assessment of higher education institutions establishment. One is that higher education in Mozambique might have operated without qualifications from its institutionalization in 1962, something that apparently shifts in 2003 with the genesis of the first systematic debates on quality.

Secondly, is that even if higher education has operated under conditions of apparent qualifications, lack of existing institutions accountable to monitor and evaluate the pace at which excellence occurred, might have contributed to lower levels in terms of results and hence the skepticism of higher education and economic development nexus in the country. Furthermore, universities have been unable to produce outcomes that are relevant for economic development considering that the product (graduates) that the country has produced were unable to test the hypothesis of quality through fitness of those to foster development.

The third challenge for the Mozambican higher education under this framework is linked to the controversy external evaluation versus the current debate that higher education in developing countries including in Mozambique is underfunded and to some extent is not yet a priority. Various 
arguments both in support and against higher education as an arena that African governments should concentrate efforts have been formulated by both researchers and funding agencies. A recent study by Cloete, Bailey \& Maassen (2011) has addressed this dichotomy and despite such research describing the status quo of the African situation as a whole, the controversy can also characterize the Mozambican higher education landscape. As they state

Higher education is now recognized as key to delivering the knowledge requirements for development. Research has suggested a strong association between higher education participation rates and levels of development, and that high levels of education are essential for the design and production of new technologies, for a country's innovative capacity and for the development of civil society. The role of higher education in development in Africa has remained unresolved. Following independence, universities were expected to be key contributors to human resource needs. The idea of 'development universities' emerged during the 1970s, when it was argued that governments should steer universities towards a development role. This was not done, partly because many governments had no coherent development models, and instead steering became interference and universities became sites of contestation. States and academics became skeptical of the role of universities in development, and higher education came to be seen as a 'luxury ancillary' - nice to have, but not necessary. During this period the World Bank, especially, concluded that development efforts in Africa should concentrate on primary education. Dramatic declines in expenditure on higher education followed: spending per student fell from USD 6800 in 1980, to USD 1200 in 2002, and later to just USD 981 in 33 low-income sub-Saharan African countries. Lack of investment in higher education delinked universities from development, led to development policies that had negative consequences for African nations, and caused the closure of institutions and areas of higher education that are critical to development. During the 1990s and early 2000s some influential voices (including the World Bank) started calling for the revitalization of African universities and for linking higher education to development. Ahead of the UNESCO World Conference on Higher Education in 2009, a group of African 


\section{Uetela - Higher Education in Mozambique}

education ministers called for improved financing of universities and a support fund to strengthen training and research in key areas. (Cloete, Bailey \& Maassen, 2011, p. ix -x).

Given that higher education investment is still a dividing debate in Africa including in Mozambique, what remains unclear is how the country has coped with outside considerable decrease of relevance in higher education forces versus the necessity for high sponsorship for external evaluation that guaranteed quality of higher education. There might be a controversy between theoretical will for external evaluation mechanisms on one hand and the empirical evidence of what has been done in higher education considering the issue of steering different operations that occur within higher education institutions has been problematic in the country due to its insufficiency to fund higher education.

Furthermore, it appears that either the strategic plans or other related policy reforms that have been taking place in higher education in Mozambique, were top formulated and down implemented. The view suggests the existence of a kind of higher education governance that is centralized, which becomes a challenge for universities in the sense that autonomy of institutions becomes threatened. As evidence suggests both for Mozambique and elsewhere, lack of involvement, empowerment of institutions and stakeholders has significantly contributed to lower outcomes. (Uetela, 2015, p. 55).

Lastly, even though the strategies, which are applied in order to monitor and assess quality of higher education institutions, appear to be borrowed, there are further concerns that the failures of higher education in Mozambique have been linked to lending policies that are not contextualized accordingly. The positive side on this domain is the fact that globalization and internationalization of higher education is steadily characterizing the landscape of Mozambique governance and policy. As a result, national politics of determining the future of higher education tend to be declining and new biographies of universities based on either global or regional patterns are substituting national agendas that have been dominant.

Despite this slight advancement, higher education in Mozambique, is still challenged by creating the workforce that pursue the knowledge that is vital in the knowledge economy as it has not yet been able to offer. Consequently, though the debate has initiated on the quality assurance in higher education 
defined in the strategic plan 2012-2020, what remains problematic is the fact that this plan and associated reforms do not address what is meant by quality of higher education in the context of Mozambique despite the shift of higher education governance and policy agendas being global. There are other problems that threaten the future of higher education in the country.

\section{Un-Contextualized Policies and Weaknesses on Governance of Higher Education}

In Mozambique, there has been an underlying focus on higher education governance as it is through the strategies applied by this that account for both failures and successes of higher education. In a recent description of higher education typologies of governance that dominate globally, Maassen (2000) has conceptualized a model common to most of African countries. He might be right in the sense that the structure of both power distribution and distance in Mozambique is too hierarchical and this impacts on how transformation policies are both designed and operationalized. (Maassen, 2000, p. 1-5). Maassen model for the African context is represented in figure 1.

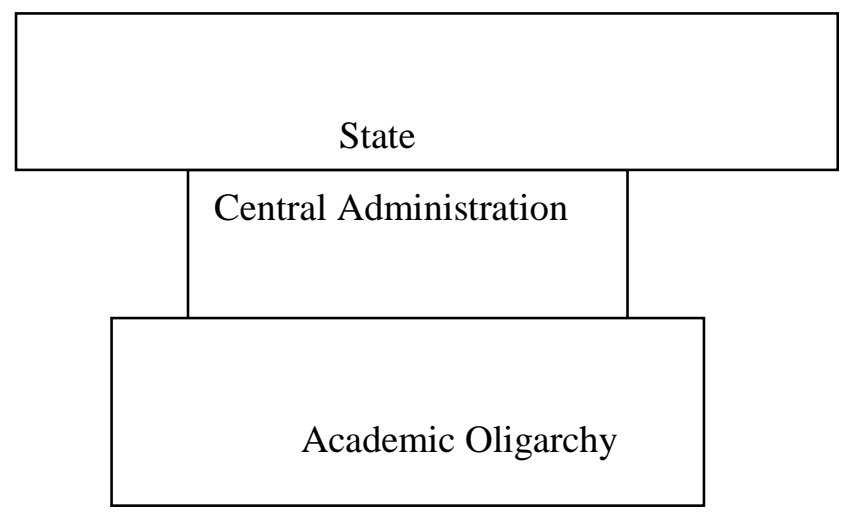

Figure 1. Higher Education Model of Governance for African States Source: Maassen (2000, p. 1-5) 
From this hierarchical order, it can be inferred that authority and the power to implement changes in Mozambique are mainly central to the state, with the academic oligarch retaining a relative autonomy and lastly the central administration at the lowest ranking of authority pyramid. How has this model then impacted on higher education transformation in the country? From the early periods of institutionalization of higher education, the state both regulated and funded higher education. The strategy placed the state as an active agent in shaping the destiny of higher education institutions and consequently an apparent passivity for the latter institutions. However, as stated previously on the concern of the complexity of both measuring and assessing quality in higher education, different stakeholders may have different approaches and understandings towards the concept. Hence, the same might occur when one assesses the conceptual frameworks that are defined by the state and universities as the guiding principles for policy and governance reforms.

In Mozambique the state seems to have comprehended in the late 1980s and earlier 1990s that, it was insufficient to both regulate and fund higher education as this implied higher levels of centralization of governance. Furthermore, the emergence of the liberal market and civil society, has put pressure on the state for power sharing with its institutions as universities claimed for apparent autonomy too. (Moyane, 2013, p. 1).

One of the underlying focus that characterized higher education at this period and the insufficiency of the state, was the emergence of the first regulatory mechanisms especially the legislation $1 / 93$ of higher education which enabled the genesis of private higher education, a considerable evidence that other forces than the state were emerging and therefore the joining efforts between the public and private sector were dawning.

Despite these changes the pyramid structure of power sharing in terms of policy reforms and governance, remained unique in the sense that, the state rather than the universities retained power to determine and legitimate decisions. This becomes evident when one analyses the two strategic plans for higher education in the country namely 2006-2010 and recently 20122020. It appears that they are not original from higher education institutions. Instead, they originate from the state as it is through the latter that are designed, legitimized and then imposed on higher education institutions as guidelines. 
In other contexts what guides governance and policy reforms in higher education, has been mainly the combined efforts of the triple helix (stateuniversities and the market). Though efforts are being made in Mozambique in order to foster power sharing and implement the triple helix model of coordination between various stakeholders in higher education, this is still a challenge in the sense that such transformation needs to be associated with a paradigm shift in leadership. It appears undeniable that the model of leadership that has characterized both states and its institutions has been based on command and control and as a result, some well known researchers in the country (cf. Bazo, 2010) have advocated for a transformational leadership as if once this occurs most of the challenges affecting both basic and higher education, will be minimized and subsequently development will take place.

Despite some of the theories described here and most of the guiding principles that characterize higher education in Mozambique being apparently exogenous (borrowed) from contexts where they have been effective and efficient, what remains outstanding is the fact that the failure of those to work can be attributed to leadership.

\section{Weakness on Knowledge Focus in a Period of Knowledge Based Economy}

In Mozambique despite recent developments in higher education with especial focus for expansion and decentralization, attaining either mass or universal higher education in the country, is still a challenge and more investments might be needed. Recent description on how higher education in the country has been neglected, has characterized the scenario as follow "Concerning the scarcity of opportunities to attend higher education, Mário et al. (2003: 20) points out that in the late 1990s, only 0.16\% of the age cohort 20-25, or 40 in every 100000 inhabitants, studied at a HEI'. (Langa, 2013, p. 65).

Despite a relative expansion of higher education in the 2000s with more higher education institutions being licensed (a total of approximately 49 in 2015), it is undeniable that the participation of all higher education aged students has not yet reached $0.5 \%$ of attendance. Neglecting higher education in Mozambique can simply imply that knowledge is not privileged 
in a period the dominium of science and technology seems to have replaced all instruments that previously shaped the attainment of growth. A recent study has described the insufficiency of knowledge investment through higher education both for Mozambique and across Africa and how the magnitude at which this knowledge was neglected has contributed to underdevelopment in a period it should be maximized as described bellow.

\begin{abstract}
[...] Africa, in particular sub-Saharan Africa comprises some of the poorest nations in the world and therefore desperately needs strong higher education systems that can assist in its rapid development. It is widely acknowledged that higher education plays a key role in the economic, scientific, social and human development of any country, and that the economically strongest nations are those with the best performing higher education sectors. Higher education, as the producer of knowledge and knowledge workers, is assuming an even more important role with the realization that knowledge, not natural resources, is the key to Africa's sustainable development. (Langa, 2014, p. xi).
\end{abstract}

There is an apparent contradiction between Mozambique current situation of higher education growth with the potential outcomes that can be predicted from the strategic plans that have been guiding higher education. Therefore, lending and borrowing policy reforms from contexts that have been able to link higher education and transformation may assist the country in its effort to grow.

Mozambique higher education has undergone three main periods of transformation namely (i) the colonization period, (ii) the socialist stage and (iii) the market economy in the $1990 \mathrm{~s}$ as represented in terms of average outcomes in graph 2. However, the nexus between these stages of transformation and economic growth remained unclear. 


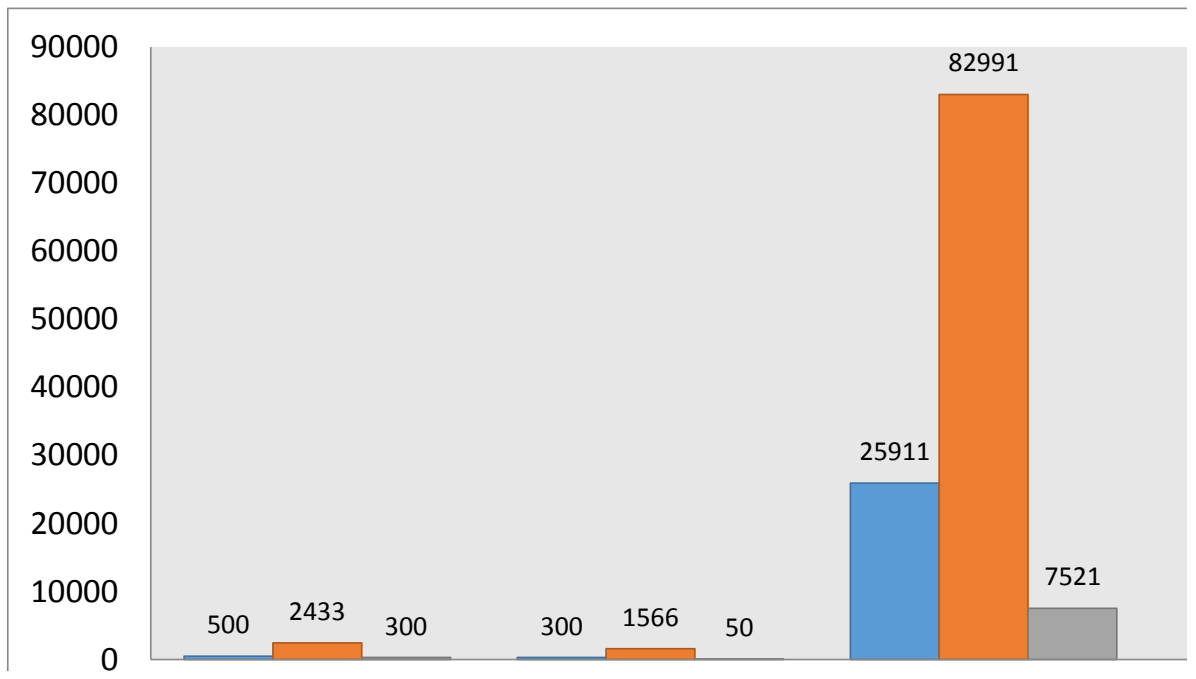

Figure 2. The evolution of higher education in Mozambique in the three periods of transformation

Source: Langa (2014), Mozambican Ministry of Education (2012, 1997)

The data outline the transformation of Mozambican higher education in the three main periods that have shaped the system. From the figures, it may be deduced that Mozambique initiated its higher education recently in 1962. In the subsequent years there was a relative average growth in the categories of inputs, out puts and total enrolments.

However, after 1975 precisely during the socialist period, there was a noticeable decrease in the three categories. There are various hypotheses that might have influenced this steady decline in higher education prioritization. (i) State institutions including higher education were nationalized which resulted in (ii) insufficiency of qualified staff, (ii) and unclear planned strategies of governance and reforms that were necessary at the period. In addition, independence meant that the Portuguese staff that was influential in the implementation of higher education in Mozambique in the 1960s might have neglected nationalization and as a result fled to their homeland.

The liberal market period in Mozambique higher education has witnessed the restoration of success in terms of enrolments, graduations and 
permanence in higher education accounting for 25.911, 7521 and 82991 average respectively in a 15-year period from 1997 to 2012 (the highest growth the country has ever seen). However, despite this achievement, Mozambique higher education remains elitist at approximately $0.2 \%$ of participation.

Within Africa, Nyangau (2014) despite acknowledging contextual differences, has characterized recent developments of countries that were able to link policy reforms and knowledge generation that enabled them to modernize in the following grounds:

[...]...The remarkable economic growth and tremendous success of Brazil, China, Korea, and Taiwan was underpinned and enhanced greatly by critical investments in a number of areas including: reforms focused at modernizing institutions of higher education; policies supportive of STEM fields; aggressive collaborative investments in academic research (R\&D) by both governments and the private sector; and clear links between higher education and the economy at both conceptual and policy levels (Johnson, 2002; Marshall, 1995; Mazzoleni, 2008; Zweig \& Rosen, 2003). Specifically, investments in higher education focused on rapid expansion of university systems, increased enrollment in general and specifically in STEM education, funding the development of public research laboratories, funding research activities collaboratively with the private sector, and creating incentives to encourage foreign-based scientists to return (Gardner, 2011; Johnson, 2002; Mazzoleni, 2008; Zweig \& Rosen, 2003). This mix of initiatives resulted in the creation of a large, skilled talent pool that continues to drive research production, technological capabilities, and ultimately economic growth in the aforementioned countries. (Nyangau, 2014, p. 9).

Since Mozambique has been unable to transform and create local strategies that foster higher education contribution for growth through indigenous policies and governance strategies, there are concerns that external experiences that have enabled the emerging economies such as the BRICS to grow, if well contextualized can empower the country for sustainable development. Thus there is a need to reform higher education through focus on (a) education and skilled labor force, (b) national system 
innovation, (c) partnerships and ICT and (d) policy and regulation. According to Nyangau (2014) and the ABD (2007) despite investments in other areas, these four (4) domains were fundamental for both Asian emerging economies and BRICS countries to attain the growth they enjoy. Thus, there is a possibility for Mozambique to engage in reforms based on these guidelines. (ABD, 2007, p. 1).

\section{Methodology}

This study was mainly based on review of existing literature on the state of higher education in Mozambique from the colonial period to the liberal market as the main method. International literature on higher education was also re-visited. The analyses were extended to policy reforms applied by the emerging economies and how these privileged knowledge in order to achieve the level of growth they enjoy at the present. The objective in so doing was not to make a comparative analysis between Mozambique and those economies. Instead it was a strategy of exploring how borrowed and lending policy reforms from contexts, which worked, can empower knowledge generation and maximization in domains that lead Mozambique for economic development and higher education nexus.

In addition, the focus and aim in so doing was to test the hypothesis that Mozambique failures to invest in knowledge generation through provision of higher education access can account for the placement of the country as one of the poorest states in the world and unless it learns from experiences that were effective, this might not be reversed.

Documents and reports available in Mozambique ministry of education and HEIs were also revisited and in order to obtain the average figures for the three categories (input, outputs and permanence) in the three periods of Mozambique higher education transformation (colonial, socialist and liberal market period), I analyzed the data availed by (Langa 2014, Mário 2003 and the statistical booklets 2006 and 2012 organized by the Mozambican ministry of education). From the data it was possible to calculate average figures for enrollments, graduations and entry in higher education under the periods herein addressed. 


\section{Conclusions}

Higher education in Mozambique is novel and an emerging field. It is affected by various upheavals and this article was aimed at addressing some of those with special focus for quality, expansion, access, un-contextualized policies and weaknesses on governance and knowledge focus in a period where knowledge based economy has considerably determined the rise of many countries. For Mozambique the link between higher education and growth remains unclear due to various threats that affect universities.

Concerning quality, though international literature has indicated how researchers have been conflicting in both defining and measuring it, in Mozambique the emergence of agencies such as the quality assurance in a context where either lack of experts in the field of quality evaluation and assessment or indexes that measure excellence are still unclear, appear to have misguided higher education institutions in the country including the strategies they had determined to foster development from the early periods.

Though expansion has considerably grown, access to higher education is still limited to few population cohorts $20-24$ at $0.2 \%$ of participation. This figure seems to suggest that higher education in Mozambique is still elitist. Considering the hypothesis of elite higher education, then social inequalities are most likely to develop in the country and universities can be seen as institutions that legitimize these differences. The challenge that higher education will face in the future is how it can reconcile expansion in an integrative strategy that lessens social disparities.

Mozambique seems to have initiated this through various reforms from the early ages of higher education institutionalization by applying policies that have worked in other contexts. The two strategic plans that have been pointed out in this article are some of those. Furthermore, the quality assurance agency and the regulatory frameworks that were pointed through out the paper are other examples that have been borrowed from other contexts.

However, it seems that Mozambique efforts to empower development through higher education will perpetually falter unless it shifts its focus with regards to mission and objectives of higher education to prioritize knowledge through (a) education and skilled labor force, (b) national system innovation, (c) partnerships and ICT and (d) policy and regulation as these 
are the key strategies applied by the emerging economies. In the case of Mozambique it appears that a new model of governance and policy of higher education should be fostered since it has been evidenced that the successes and failures of any organization including schools is often determined by leadership, hence it appears that a novel typology of leading higher education, needs to be implemented.

\section{References}

ADB. (2007). Moving Toward Knowledge-Based Economies: Asian Experiences, a Technical Note. Manila: Asian Development Bank, 1 $-57$.

Agbo, S. (2003). Myths and realities of higher education as a vehicle for national building in developing countries: The culture of the university and the new African diaspora. Pacific University Oregon.

Bazo, M. (2010). Transformational Leadership in Mozambican Primary Schools. PhD Thesis, University of Twente. Enschede: PrintPartners Ipskamp.

Castells, M. (2001). Universities as Dynamic Systems of Contradictory Functions. In muller, $\mathrm{j}$ (eds) Higher Education and the Network Society.

Chang, Ha-Joon. (2010). Things They Don't Tell You about Capitalism. Allan Lane Penguin Books: London.

Langa, P. (2013). Higher education in portuguese speaking countries. Cape Town: African Minds

Maassen, P. (2000). Higher Education Research. The Hourglass Structure and its Implications. In Teichler et al (Eds). Higher Education research. Its relationship to policy and practice. Perganon

Moyane, S. (2013). Democracia e Desenvolvimento versus Ensino Superior em Moçambique Quelimane: Universidade Lúrio, Palestra

Mozambican strategic plan for higher education (2012-2020). Mozambican ministry of education: Maputo, 2012.

Nyangau, J. (2014). Higher education as an instrument of economic growth in Kenya. Forum for international research in education, 1(1), 7-25. 
Peters, G. (2013). Habitus, Reflexividade e Neo-objetivismo na teoria da pratica de Pierre Bourdieu. Revista Brasileira de Ciencias Sociais, 28(83), 47-71.

Premugy, C. (2012). Coletânea da Legislação do Ensino Superior: Ministério da Educação: Direção para a Coordenação do Ensino Superior. Maputo: Edições Revista.

Uetela, P. (2015). Sociology of organizations as a mechanism of learning: An address from the Mozambican School organization. Meditações Journal, 9(16), 44-59.

Pedro Uetela is $\mathrm{PhD}$ Candidate at the Universidade Estadual Paulista Júlio de Mesquita Filho, Brasil.

Contact Address: Direct correspondence to Pedro Uetela Muñoz at Universidade Estadual Paulista Júlio de Mesquita Filho, Centro Educacional, Pres. Prudente - SP, 19060-900, Brasil. E-mail: uetelaha@yahoo.com 